\title{
On the use of posture verbs by French-speaking learners of Dutch: A corpus-based study
}

\author{
MAARTEN LEMMENS and JULIEN PERREZ*
}

\section{Abstract}

This article presents the results of a quantitative and qualitative corpus study of the use of the Dutch posture verbs staan ('stand'), liggen ('lie') and zitten ('sit') by French-speaking learners of Dutch. In addition to providing a quantified insight into which uses of these verbs prove most problematic to the L2 learners, the study has also revealed three important tendencies. Firstly, in line with the typological differences between French and Dutch (where these verbs behave like noun classifiers), our analysis confirms the French-driven tendency of the learners for underusing these verbs. Secondly, seemingly paradoxical to the previous point, is that these learners occasionally overuse these posture verbs in contexts where no such verb is allowed. Thirdly, our qualitative analysis of errors reveals that the learners operate on grammaticised semantic distinctions drawn from the target language. Even if the categories used by L2 speakers may not be the same as those exploited by native speakers, our analysis suggests that the L2 speakers are thus aware of the patterns in the input and exploit them in a fashion that may not differ all that much in kind from those in L1 acquisition.

Keywords: $\quad$ posture verbs, Dutch, second language acquisition, learner corpus, lexical, overgeneralisation.

* Address for correspondence: M. Lemmens, Professeur en linguistique et didactique des langues, UFR Angellier, Université de Lille 3, B.P. 60149, 59653 Villeneuve d'Ascq CEDEX, France. Email: maarten.lemmens@univ-lille3.fr; J. Perrez, Facultés Universitaires Saint-Louis (FUSL), Boulevard du Jardin botanique 43, 1000 Bruxelles, Belgium. Email: perrez@fusl.ac.be; Acknowledgements: The authors wish to thank the editors of this special issue (Henriette Hendriks, Maya Hickmann and Katrin Lindner), Sabine De Knop, Philippe Hiligsmann, Aliyah Morgenstern and the two anonymous reviewers for their constructive comments on an earlier version of this paper. The authors are responsible for any errors that remain. 


\section{Introduction}

\subsection{Scope and issues}

Anyone familiar with the teaching of Dutch as a foreign language will know that the use of the three cardinal posture verbs zitten ('sit'), liggen ('lie') and staan ('stand') are often quite problematic for learners. In this paper, we present the results of a corpus-based study, in which we looked at how these verbs are used by Belgian francophone learners of Dutch. ${ }^{1}$ We approach the data from a quantitative as well as a qualitative perspective. The quantitative analysis allows us to evaluate in which uses the difficulties are mostly situated. The qualitative analysis discusses some of the mechanisms that lead L2 speakers to produce these errors.

The present study is but a first (yet essential) step towards a more systematic analysis of the use of posture and location verbs in learner data (in Dutch as well as other languages) and will be followed by comparative research drawing on more controlled (spoken) data along the lines of earlier research in this domain (cf. Lemmens 2005a). Notwithstanding its modesty in scope, our corpus data support a usage-based model of (second) language acquisition, suggesting evidence for partially unit-based learning strategies as well as for systematic overgeneralisations of acquired patterns, much like what is known to occur in L1-acquisition. While the semantic categories with which the learners operate may not be the same as those of the native speakers, the learners' errors show that the learner language is a linguistic system, in which grammaticised semantic distinctions drawn from the target language do play an important role (Klein 2008; cf. also Klein and Perdue 1993; Hiligsmann 1997). If it weren't for this (partial) semanticisation, we could not explain the apparent paradox in the L2-data, i.e., the undeniable (typologically determined) underuse of the posture verbs in general, combined with "posture verb overkill" in many of the sentences in which these verbs do occur.

\subsection{Typological background}

In earlier work (Lemmens 2002), one of the authors has characterized the difficulty that francophone learners of Dutch have with posture verbs as being situated on three interrelated levels: (i) coding flexibility, (ii) coding variability and (iii) coding obligation. As the term suggest, coding flexibil-

1. The present study focuses on Dutch as spoken in Flanders, the Dutch-speaking part of Belgium, which is also the variant with which the French-speaking learners in this study will be most regularly confronted (even if not exclusively). There are some interesting differences between Belgian and Netherlandic Dutch concerning the use of posture verbs (cf. also Lemmens 2006). 
ity refers to the wide range of semantic extensions (semasiological variation) that the posture verbs have in Dutch, since they have grammaticalised to basic locational verbs that are not only used to refer to the basic human postures, but also to the location of any entity in space or metaphorical extensions thereof (cf. section 1.3 below).

The second difficulty concerns the coding variation, which represents the other side of the coding coin (onomasiological variation), since one and the same spatial configuration, such as for example in De boter in de koelkast ("the butter in the refrigerator') may be coded either with staan (in which case it metonymically refers to the butter dish 'standing' on its base), with liggen (in which case it talks about the package typically lying on its longest side), or with zitten (an "a-positional" usage referring to containment only). Each of those verbs clearly imposes its own semantic profile on the scene; the choice of verb cannot be predicted with absolute certainty based on dimensions of the located object (although these dimensions may play a role in certain contexts). Often, (French) L2 speakers are mislead by these dimensions, saying for example that a bed in a room or a plate on the table (entities with a salient horizontal dimension/orientation) are 'lying' whereas in Dutch staan ('stand') is to be used.

The third level of difficulty, the coding obligation, concerns the fact that the use of a posture verb is obligatory in Dutch whenever an entity is located in space, whereas in English and in French, it is quite common (if not obligatory) to use a verb of EXISTENCE (such as be/être) in locative predications, as illustrated in example (1) below. ${ }^{2}$

(1) a. my keys are on the table / the car is in front of the house

b. mes clés sont sur la table / la voiture est devant la maison

c. mijn sleutels liggen (*zijn) op de tafel / de auto staat (*is) voor het huis

While in English one could still use lie and stand in these two contexts (even if often giving a more stilted formulation), this is quite infelicitous in French: *mes clés sont couchées sur la table / *la voiture est debout devant la maison. The coding obligation in Dutch also holds for many metaphorical uses (even if some leniency is to be attributed to these, cf. Section 3 below).

In short, not only do francophone learners of Dutch have to go against their native speaker intuitions and use a posture verb instead of a neutral

2. Examples without a reference have been constructed by the authors (possibly varying on attested uses in other corpora), examples from the corpus will be marked with an IDnumber, and examples found via Google will have a URL reference. 
verb, they are also confronted with considerable semasiological and onomasiological variation. While this typological difference, related to that between Verb-framed and Satellite-framed languages (see Talmy 2000), has been discussed in earlier work (see, e.g., Lemmens 2005a; Lemmens and Slobin 2008 and the references therein), similar observations have been made in some other recent publications. Of note is the special issue of Linguistics edited by Ameka and Levinson (2007), devoted to location and posture verbs in a typologically varied language sample. While French is not included in their comparative study, the typological distinction between French and Dutch would in their terminology be cast as that between a Type I language (using a single locative "dummy" verb) versus a Type II language using a small set of locative verbs (typically, but not exclusively, posture verbs, as in Dutch).

Before we turn to a more detailed discussion of the use of posture verbs in L2 productions, it is essential that we briefly review some of the main patterns of use for the three posture verbs in Dutch, presented in the next section. Restricted to patterns that are immediately relevant to the L2 data, the description is but a summary of more elaborate descriptions of the Dutch posture verbs presented elsewhere (Lemmens 2002, 2006).

\subsection{A short overview of Dutch posture verbs}

In line with the basic assumptions of Cognitive Grammar, the Dutch posture verbs liggen, zitten, and staan can safely be said to be structured around a prototype, the representation of the three basic human positions. As Newman (2002) correctly observes, these prototypes are "experiential clusters" of attributes and the extended uses can be explained drawing on the notion of image schemata based on our everyday experience of lying, standing, sitting.

Classifying the extensive networks in broad strokes, we can distinguish three types of uses: postural uses, referring to human posture; locational uses, referring to the location of any entity in space; and metaphorical uses, referring to location in abstract space or location of abstract entities in concrete space. The following sections will look at some of the extensions in more detail.

1.3.1. Staan. The most important uses of staan can be summarized as in the schema below.

(i) BE ON ONE'S FEET $\Rightarrow$ BE ON ONE'S BASE

(ii) $\Leftrightarrow$ EXTEND UPWARD FROM BASE (ORIGIN) $\Rightarrow$ EXTEND FROM ORIGIN IN ANY DIRECTION

(iii) HAVE A VERTICAL ORIENTATION (ABSENCE OF BASE OR NOT ON BASE) 
(iv) BE IN CANONICAL POSITION

(v) WRITTEN TEXT AS STANDING

The image of an object on its base, a logical extension of the prototype configuration of a human being on its feet, is undoubtedly the most productive one within the locational domain. In an earlier corpus study (Lemmens 2002), it was shown to account for almost $60 \%$ of the locational uses. Its conceptual importance is further reflected in the fact that the real dimensions of the object do not play a role anymore: for any object resting on its base, a coding with staan becomes the most likely candidate, even if it is more horizontal than vertical, as is the case for cars, plates or laptops, which are said to be standing when resting on their base. Considering cognitive processing, one could argue, as does Serra Borneto (1996) discussing German stehen ('stand'), that the conceptualisation of a base triggers a mental verticality, i.e., the mental image of an upward extension of an object taking the base as its origin. ${ }^{3}$ Typically, the situation involves a vertical extension (e.g., trees or grass growing upwards from their roots and thus 'standing'), but through image schematic transformation (rotation), the verb can also be applied in contexts where non-vertical direction is at issue, as in Er staan geen takken meer aan deze boom 'There stand no branches to this tree anymore'. ${ }^{4}$ Such uses of staan do not express verticality but a (moderate) form of perpendicularity. ${ }^{5}$

Verticality only comes in as a determinative factor in the absence of a base, as in (2a), or when the object is not resting upon its base and verticality is needed to identify its orientation, as in (2b).

(2) a. Het boek staat in het rek. / De golfstok staat in de paraplubak. the book stands on the shelf / the golfclub stands in the umbrella holder.

b. De borden staan in de afwasmachine / De fles stond omgekeerd op tafel.

the dishes stand in the dish washer / the bottle stood upsidedown on (the) table

It is particularly in this case that staan provides a maximal opposition with liggen. Before continuing with liggen and zitten, however, we need

3. On German posture verbs, see also Fagan 1991 and Kutscher and Schultze-Berndt 2007.

4. The English glosses are but literal translations of the Dutch originals using as much as possible the English equivalents sit, lie, or stand.

5. Dutch is not isolated in this. Perpendicularity is a notion also important for example to a language as Trumai, a genetic isolate spoken in Brazil (cf. Guirardello-Damian 2002). 
to mention a few metaphorical extensions for staan that will be immediately relevant to the L2-data.

The first (extension (iv) in the schema above) concerns a number of different uses that all relate to the idea of standing as the canonical position for human beings (cf. also Van Oosten 1984: 144). There are a number of (non-linguistic) arguments to justify this claim. First, standing upright is the position that most distinguishes the human being (homo erectus) from other species, esp. primates. Moreover, standing is the starting position for the proto-archetype of human, self-propelled movement, viz. walking or running (on two legs). Related to this is that, when standing, humans are physically stronger than when sitting or lying and generally have better control over their body movements. Humans in a standing position are also perceptually more distinguishable from their surroundings (cf. the metaphor stand out and outstanding). In short, human beings physically function best when in a standing position, feeding the idea of canonicity. But also other sources can serve to confirm the canonicity: if you ask someone to quickly draw a human being, they will typically draw a standing figure. ${ }^{6}$ Finally, returning to the domain of linguistic meaning, it can be seen that many extensions, locational and metaphorical, draw precisely on standing as the canonical position. This is especially true for Dutch where, as explained above, staan has become the conventionalized coding for any object resting on its base, the default position also being the object's optimal position, i.e., the functional position it has been designed for.

In short, standing being the canonical position for human beings, motivates the use of staan to refer to a human being's default posture, even when posture is backgrounded or even no longer at issue. ${ }^{7}$ This is reinforced by the use of the verb to refer to objects in their normal (i.e., functional) position. This pertains to our study in two different ways. First, it may help to explain why staan is used in contexts where there may still be a reference to the standing posture as the most typical posture for the activity at hand, but where there is some non-postural reading as well. A typical case is that of working as a teacher or as a shopkeeper, where you would commonly say (at least in Belgian Dutch) ik sta in het onderwijs ('I stand in the education') or Ik sta in een herenboetiek ('I stand in a clothes

6. Notice that the standing position is also the way in which humans are represented in handbooks on human anatomy.

7. Clearly, motivation does not equate prediction, as the notion of canonical position can be overruled by for example cultural factors. In Ese Ejja, for example, an endangered language (Tacana family) spoken in Peru and Bolivia, for some contexts the default position for men is neki ('stand'), that for women, ani ('sit') (Vuillermet 2008). 
boutique for men'). Typically, one stands in front of the class room when teaching or behind the counter when running a shop, but both sentences do more than just refer to that postural configuration, referring to the job as a whole, which involves many more kinds of activities than just standing (walking around, sitting and correcting exams, etc.). Notice that for other types of jobs, if one wants to use a posture verb at all, it will be zitten (e.g., Hij zit in de computerbranche 'He sits in the computer business'), but this is an a-postural use of the verb referring to CONTAINMENT (cf. section 1.3.3 below).

Second, and more important than the above cases which are rather limited, there are cases where a standing posture is no longer at issue at all, and staan simply refers to the default position. This has given rise to a wide range of extended uses, as illustrated by the following examples:

(3) a. De politici staan tegenwoordig veel dichter bij de burgers. politicians these days stand much closer to the citizens

b. Hoe sta jij tegenover de nieuwe spelling? how do you stand against the new spelling (= What's your position about...)

c. Dit thema staat te ver van de leefwereld van het kind (DL1-S$0278)^{8}$

this theme stands too far from the world of the child (= is too remote from)

Such uses are clearly no longer postural or locational, as they concern one's ideological position on certain issues or simply the position of one entity vis-à-vis another. At the same time, the use of staan is well motivated here, as there still is a link with being in one's default position, particularly since it mostly conceptualises the located entities as being 'placed' there. It cannot be denied, however, that the link that can be construed with one's default position is of variable strength in these uses, suggesting a gradient of "metaphorisation". For example, while all uses in the example above are metaphorical, there is arguably a cline ranging from (a) (least metaphorical) to (c) (most metaphorical).

The second metaphorical extension that plays an important role in both the L1 and L2 data is that of written text, which in Dutch is invariably coded with staan, as illustrated in the following examples:

8. References to corpus examples such as this one consist of 3 parts: (1) DL1 or DL2 identifying it as taken from the Dutch L1 or L2 corpus respectively, (2) the letters $S, Z, L$ referring to resp. staan, zitten, and liggen, and (3) a number identifying the sentence in question. 
(4) a. Wat staat er op deze pagina? what stands there on this page?

b. Sommigen staan op een wachtlijst. (metonymy: NAME / PEOPLE) some (people) stand on a waiting list

The motivation behind this use is probably no longer transparent even to native speakers; nevertheless, two converging factors can still be attributed some motivating force (and this regardless of whether they are etymologically accurate). First, there is the image of text 'standing' on the supporting paper, as if in relief. In order to be readable, letters must be placed on their flat side, which thus becomes their base. The mental scanning vector is thus from the paper upwards to the top surface of the printed letter. Second, letters can be seen as 'standing' on (visible or invisible) horizontal lines on the paper. Hence, you write on the line, the letters have a height. The mental scanning vector is thus different, perpendicular to the previous one, going from the bottom of the line to the smallest top of the letter. We thus disagree with Serra Borneto (1996) who analyses similar uses of German stehen ('stand') as resulting from the metaphor WRITTEN TEXT AS VERTICAL ORDERING; we do agree with him, however, when he says that "the figurative extension, which started from a perceptual image, has established itself in the conventional knowledge of the speakers and is now active, independently from the original spatial image" (1996: 477).

Whatever its motivation, it is clear that this usage has become highly entrenched to the extent that it has laid the basis for extensions to all kinds of imprints (including non-textual ones), of either temporal or permanent nature, such as pictures in a book, text or icons on a screen, marks on the body. All of these can, and often must, be coded with staan. Within the prototypically structured radial network encoded by staan, this usage could be characterized as a local prototype from which new uses extend. The discussion in section 3.2 below will consider the importance of this local prototype for the L2 data.

1.3.2. Liggen. The following is an overview of the most important uses of liggen that will be briefly discussed here:

(i) BE ON ONE'S SIDES (human posture)

$\Leftrightarrow$ NOT BE ON BASE WITH HORIZONTAL ORIENTATION (inanimate entities)

$\stackrel{4}{\rightarrow}$ NOT BE ON ONE'S BASE (REGARDLESS OF ORIENTATION)

(ii) LOCATION OF DIMENSION-LESS ENTITIES

(iii) GEOTOPOGRAPHICAL LOCATION (cities, buildings, etc.)

(iv) LOCATION OF ABSTRACT ENTITIES 
Horizontality is much more important for liggen than verticality is for staan. This horizontality manifests itself in different types. Two large categories of horizontal objects can be distinguished, LINE types and SHEET types, which are maximally distinct in their prototypes but share a transitional zone (small boards, for example, are conceivable as wide lines yet also as small elongated sheets). Within the SHEET category are also included different kinds of tissues (e.g., clothes, towels, etc.) and substances (e.g., liquids, sand, etc.), since they are non-rigid objects that naturally take a horizontal expansion under their own gravitational weight. The difference between Het zout ligt op tafel and Het zout staat op tafel ('The salt stands/lies on the table') is thus metonymical: in the first case, liggen refers to the salt as substance which, unconstrained by any fixed boundaries, will flatten out on the table; in the second case, staan shifts the focus from the substance itself to the saltshaker (itself left implicit however), posited on its base, and thus in a 'standing' position.

One of the particularities of Dutch (but something one finds in other languages as well) is that it has conventionalized the verb liggen to encode the location of symmetrical entities (balls, cubes, wads, etc.). These can be characterized by a "lack of dimensional salience" as Serra Borneto (1996) correctly observes for German liegen, perfectly similar to Dutch in this context. He points out how in the absence of dimensional differentiation there is no mental tracing away from the origin that one has with vertical objects or objects resting on their base.

The 'dimension-less use' of liggen motivates a number of metaphorical extensions concerning the "location" of abstract entities. We are not referring here to the cases where these abstract issues are saliently associated with a particular horizontal form, as may be the case for example with frontiers conceived as lines, or foundations as horizontal supports. The abstract uses that we are concerned with here are those entities that seem to lack such imagery, as for example in De verantwoordelijkheid ligt bij jou 'The responsibility lies with you'. We will not go into detail as to what motivates this extension (see Lemmens 2006); for our present purposes it suffices to point out the entrenchment of liggen as the usual encoding for abstract entities.

Another particularly well-entrenched usage of liggen in Dutch is that of "geotopographical location" as Serra Borneto (1996) has called it. This concerns cases where buildings, cities, and the like are located geographically. Even when standing right in front of a quite saliently vertical building, like a church, that typically is thought of as standing (resting on its base), we can still felicitously say, e.g., De kerk lag pal voor ons 'the church lay right in front of us'; in that case, we would obviously not be talking about it as a building, but about its geographical location. As we 
will detail below, some interesting (erroneous) patterns for this usage emerge from the L2-data.

1.3.3. Zitten. The most important uses of zitten can be summarized as follows:

(i) BE IN A SITTING POSTURE (considerable postural variation)

$\Leftrightarrow$ DEFAULT POSTURE OF SMALL ANIMALS

$\Leftrightarrow$ DEFAULT POSTURE OF INSECTS

(ii) (CLOSE) CONTAINMENT (locational usage)

(iii) (CLOSE) CONTACT (locational usage) $)^{9}$

Strikingly, zitten shows considerably more variety in the postural domain than do liggen and staan, as it is used for a diversity of positions: (i) resting on the buttocks like on a chair (prototype posture for zitten), or (ii) with the legs crossed (yoga-position), or (iii) with legs stretched out; (iv) a squatting position; (v) on all fours; (vi) on hands and knees; or (vii) on one's knees. Interestingly, some of the extended uses of zitten can be explained from these postural variations. For instance, in a squatting position, the lower legs are bent, the body is close to the ground and often, there is an additional support with our hands on the ground. This postural configuration motivates the use of zitten to express the default position of lower animals such as rabbits, mice, frogs, etc. who usually are not said to 'stand'. In the domain of animal postures, zitten has even gone further in that it is also the default verb for insects that, just as frogs and mice etc., only have a dual postural opposition zitten-liggen (the latter being used, for example, when they are dead). In the absence of postural variation, not much of the notion of posture is probably retained in these uses. The postureless nature of these uses, in combination with the postural variety sketched above, may explain the verb's noncommitment to posture and its productive extensions to other postureless uses. The most important one immediately relevant to the L2-data, is what we conveniently label CONTAINMENT-zitten.

In the case of CONTAINMENT-zitten the verb no longer encodes posture but merely situates the entity as (closely) contained by a container. Hence the use of zitten to refer to water in a bottle, money in your pocket, a key in the keyhole, dust in your hair, a CD in a CD-case, etc., but also people 'sitting' in prison or in a hotel room, etc. When used with inanimate enti-

9. While this extension is quite important for zitten, where the verb expresses close contact, as for example in Er zit geen deurknop aan deze deur 'there sits no doorknob on this door', it turned out to be irrelevant to this study and will thus be ignored. 
ties, the contexts usually concern close containment or cases where the position of the contained entity depends on that of the container. As can be expected, zitten is also often used when metaphorical containment is at issue, such as suspense 'sitting' in a race, or a bug 'sitting' in a computer system, or the meaning 'sitting' in a word or text. As we will show, the latter will be of particular interest for our L2-data. The productivity of CONTAINMENT-zitten is clearly illustrated by the L1-corpus used in our study: $64 \%$ of the cases refer to containment. ${ }^{10}$

As has become clear from the above discussion, the three cardinal posture verbs zitten, staan, and liggen have become basic location verbs in Dutch. While many uses of their extensive semantic networks have not been discussed here, the above summary has revealed the basic semantic mechanisms that underlie their most important uses. Considering their locational uses, and particularly the variations that may exist (such as a building said to 'lie' or 'stand', or salt on the table as 'lying' or 'standing', or butter 'lying', 'sitting', or 'standing' in the fridge), we could say that the Dutch posture verbs actually function as noun classifiers, just as noun suffixes may do in more 'exotic' languages, specifying that the noun in question refers to an entity that is liquid, oblong-shaped, pointed, rigid, sand-like, sticky, tubular, etc. Clearly, the Dutch categories are less refined than in many of these languages, yet the parallel with how the Dutch posture verbs indeed categorize the located entities cannot be denied. Interestingly, Gullberg's analysis of gestures confirms this idea, showing that "Dutch speakers are significantly more likely to incorporate figure object information in their gestures than are French speakers" (Gullberg to appear; see also Gullberg and Narashimhan, this volume).

Using these posture verbs in an idiomatically correct way is quite hard to master for French-speaking learners of Dutch. The study discussed here is a first attempt at clarifying these difficulties in more detail and preparing the ground for further research. Before turning to the actual quantitative and qualitative analysis, it is appropriate to say a few words about the corpora used (L1 and L2) and how we analysed them.

\subsection{Corpus and corpus analysis}

This study is based on two corpora: a learner corpus (DL2) and a control corpus (DL1). The learner corpus is a selection from the Leerdercorpus Nederlands ('Learner corpus Dutch'; see Perrez and Degand, in prep.).

10. This percentage lines up nicely with another corpus-based study (Lemmens 2002), where some $50 \%$ of the 4,311 sentences with zitten referred to containment. 
This corpus is a collection of texts written by learners of Dutch from different L1-backgrounds (French, German, Polish, Indonesian and Hungarian). Our 'French' selection is drawn from (i) a series of argumentative essays written by French-speaking learners of Dutch studying Dutch as a main option and (ii) writing tasks performed by French learners of Dutch in the context of the CNaVT-exam ${ }^{11}$. The latter texts show a greater diversity, ranging from essays, summaries and reports, to letters and e-mails. For each text, some meta-information has been recorded concerning the author (mother tongue, study level and orientation) and the text itself (type of text, year, CNaVT-profile). In total, the French DL2subcorpus contains 1,247 texts amounting to 323,921 words. The control corpus (DL1) is composed of a range of argumentative essays written by native speakers of Belgian Dutch in the framework of a writing proficiency class (first year university students, Ghent University). The size of the corpus is admittedly rather limited (approximately 52,000 words) but its primary interest lies in its argumentative nature which matches quite well the main type of texts in the learner corpus.

Our study of posture verbs on the basis of these corpora is not without limitations. Firstly, argumentative texts are not really representative of the contexts in which posture verbs typically occur, which may result in a limited number of attestations. The planned follow-up studies on spoken data will surely overcome this limitation. Secondly, as indicated before, it is essentially restricted to Belgian Dutch; some of the uses mentioned here may not be common in Netherlandic Dutch. Thirdly, for written corpora it is not always possible to reconstruct the contexts in which they have been produced, which makes it occasionally difficult for the researcher to interpret the learner's intentions in having used a given posture verb. Finally, the absence of an objectively determined indication of the individual levels of proficiency did not allow a reliable investigation into the evolution over the different levels. Despite these limitations, our study has revealed relevant tendencies concerning the use of posture verbs by French-speaking learners of Dutch.

In line with the above analysis of staan, liggen and zitten, we coded, for both the L1 and L2 corpus, the different semantic categories that these verbs are used in. This has been done at two levels of detail. At the highest level, a distinction was made between postural, locational and metaphorical uses of the verbs. In addition to these three categories, we distin-

11. The Certificaat Nederlands als Vreemde Taal $(C N a V T)$ is an internationally recognized certificate for students of Dutch comparable to the Cambridge Certificate in Advanced English. 
guished two other categories at the highest level, viz. the use of the posture verb (i) as root of a particle verb construction and (ii) as part of an idiomatic expression. The former category refers to cases where one of the posture verbs is combined with a particle (such as opstaan 'get up (from bed)' or toestaan 'allow'), whereas the latter category refers to fixed collocational uses (such as bekend staan 'be famous' or onder stress staan 'be under stress') as well as cases where a posture verb is used as part of a fixed multiword unit (in combination with a preposition, an adverb, an adjective and/or a noun) whose global meaning cannot be derived from the meaning of its components in isolation. ${ }^{12}$ Examples are voor de hand liggen (lie before the hand = 'be evident'), op eigen benen staan (stand on own legs $=$ 'be independent'), or het niet meer zien zitten (not see it sit any longer $=$ 'not able to see one's way out of a situation').

The motivation for separating these two categories is, firstly, that the meaning of the verb in these constructions is often quite remote from its postural or locational meaning. Secondly, French-speaking learners of Dutch, when using such constructions, arguably do not really intend to use a posture verb, but rather directly translate a French construction (Il est évident que... , 'It is clear that') into a Dutch counterpart that simply happens to be built with a posture verb (Het staat vast dat... 'it stands fixed ( $=$ is) clear that'). In other words, the use by the learners of staan in vaststaan does not say anything about their ability to use the posture verb properly, but would rather be part of a unit-based learning strategy.

At a more refined level, additional codes were used to further specify the use of the posture verb within the larger categories described above. This is particularly relevant to the locational and metaphorical uses of the verbs. Such further specification allows us to determine what type of location the posture verb refers to (e.g., geotopographical location, documents on a desk, etc. for liggen or containment for zitten) or what type of metaphorical use was at issue (e.g., abstract entities or scales for liggen; canonical position or written text for staan; containment, or 'stuckness' for zitten). Some of these labels probably deserve some further comments. For instance, the label 'containment' for zitten has been applied to locational as well as metaphorical uses. The difference between these two lies

12. In order to avoid a subjective labeling, we have used as a reference the Van Dale Groot Woordenboek Nederlands-Frans bilingual dictionary to establish whether a given structure should be considered as an idiomatic expression or not. While obviously the dictionary cannot be taken as a flawless norm, we believe that the choice is further justified by the observation that this is the resource that French L2 learners are most likely to turn to. Only for a handful of cases, where it clearly concerned an omission in the dictionary, was the label a decision of the authors. 
in the nature of the container, which is concrete in the former, example

(5) but abstract in the latter ones, example (6). ${ }^{13}$

\section{locational:containment}

(5) Ik zit namelijk op kot en heb geen kabelaansluiting in huis. (DL2-Z0042)

I sit (= live) in a student room and don't have any cable connection there.

\section{metaphor:containment}

(6) Na het treinongeval en de reis beseft hij waar hij in zijn leven zit. (DL2-Z-0053)

after the train accident and the journey, he realises where he sits (= is, stands) in his life

The further specifications for staan also deserve some comments. In the description of the locational use of staan, we specified whether this location was canonical, referring to contexts where the location is concurrently related to the default position of a human being or of an object (resting on its base) as in example (7).

(7) Dus de producten zullen op een logische plek in de winkel staan en het zal gemakkelijker voor de klant zijn. (DL2-S-0040)

thus the products will stand in a logic location in the store and it will be easier for the customer.

The label canonical has also been used to qualify some of the metaphorical uses of the verb. In these cases, it refers to metaphorical extensions of staan that can still be related to its postural or locational meaning (see example (3b) above). The other metaphorical uses concern cases where staan could not directly be linked with its postural or locational meaning (see example (3c) above).

The coding scheme as described here has been applied to all of the sentences in the DL1-corpus and all correct uses in the DL2-corpus. The cases where the L2-users did not use the posture verb correctly were set apart at the highest level via the label 'error', so as to ensure that statistics on the distribution of usage only applied to correct cases. On a more refined level, we then coded a specification of the different types of errors made by the French-speaking learners of Dutch. These different types of

13. The examples from the DL2 corpus are reproduced in their original form; it may thus be that there are other language errors than the ones that we are interested in (such as the infelicitous use of in huis in this example). These errors will be ignored here. 
errors will be discussed extensively in the subsequent sections. Before we turn to them, some important methodological observations have to be made concerning the corpus analysis as described here.

Firstly, it should be clear that the coding scheme described above has its methodological limitations. The codes are set up as heuristic tools to allow qualitative and quantitative analysis, but the resulting categorization should not be taken as reflecting a final and fixed map of the meanings of these verbs. For one thing, it may in some cases not always be easy to distinguish between certain categories, for example, with contexts where both a postural and locational reading could be entertained. The absence of clear-cut distinctions is also nicely illustrated by the degrees of metaphorisation illustrated above.

Secondly, while we strongly prefer corpus-based analysis over intuitionbased analysis, the latter cannot be excluded when evaluating L2productions. To assess our data as objectively as possible, all fragments have first been analyzed by both authors separately, for which, as became apparent in the subsequent comparison, there was a high degree of agreement. Problematic cases were further discussed and submitted to the judgment of minimally two other native speakers of Belgian Dutch.

\section{Quantitative analysis of $\mathbf{L 2}$ data}

\subsection{Overall frequencies}

In total, 557 sentences have been extracted in which one of the three posture verbs occurred (407 fragments from the learner corpus and 150 from the control corpus). A first general observation is that staan is the most frequently used posture verb in both corpora. In the control corpus, it is followed by liggen and zitten respectively, whereas in the learner data, zitten is slightly more frequent than liggen (cf. Table 1) ${ }^{14}$. Further comparison between the L1 and L2 data show that, in line with the typological differences between French and Dutch, the learners globally tend to underuse the posture verbs in their L2 productions (62.85 vs. 143.95

14. The DL1 frequency distribution (staan $>$ liggen $>$ zitten) does not exactly replicate the one given in Lemmens (2002) (staan > zitten > liggen), in which zitten even appeared to be almost as frequent as staan. This can probably be explained by the different types of texts analysed in the latter study, i.e., newspaper articles versus argumentative essays in the present study. 
Table 1. Distribution of liggen, staan and zitten in the learner and control corpora

\begin{tabular}{|c|c|c|c|c|}
\hline \multirow[t]{2}{*}{ Verbs } & \multicolumn{2}{|c|}{$\begin{array}{c}\text { Control } \\
52,056 \text { words }\end{array}$} & \multicolumn{2}{|c|}{$\begin{array}{c}\text { Learner } \\
323,921 \text { words }\end{array}$} \\
\hline & Occ. & Freq./50,000 & Occ. & Freq. $/ 50,000$ \\
\hline liggen & 55 & 52.8 & 88 & 13.6 \\
\hline staan & 73 & 70.05 & 209 & 32.25 \\
\hline zitten & 22 & 21.1 & 110 & 17 \\
\hline Total & 150 & 143.95 & 407 & 62.85 \\
\hline
\end{tabular}

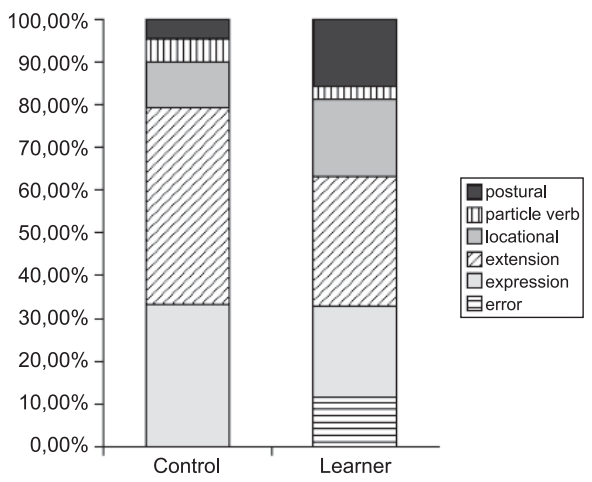

Figure 1. Distribution of the posture verbs across their categories of use

occurrences per 50,000 words). ${ }^{15}$ This is more outspoken for liggen and staan than for zitten. ${ }^{16}$

A more detailed analysis of how the posture verbs are used by the L1speakers and the learners respectively points to some interesting tendencies, as illustrated by Fig. 1. A first observation is that the learners appear

15. Given the unequal size of the learner and control corpora, the frequencies in Table 1 have been normalized to 50,000 words, the greatest common decimal factor; such a procedure is not uncommon in corpus linguistic studies for frequencies in large data sets (see, e.g., Newman and Rice 2004). In the smaller data sets (e.g., Tables 2 and 3) standard percentages are used.

16. The tendency of Francophone L2 speakers of Dutch to underuse posture verbs and overuse of location verbs (the latter issue is not considered here) is confirmed by a pilot study (Lemmens 2001) comparing picture descriptions: native speakers of Belgian Dutch used posture verbs in $58 \%$ of the locational phrases, whereas the French learners only used them in $19 \%$ of the cases and resorted to a location verb in $63 \%$ of the cases $(\mathrm{p}<0.0005)$. 
to use posture verbs inappropriately in about $11 \%$ of the cases; these will be discussed more extensively in sections 2.4 and 3. While we have labelled them as "errors" which, from a L1 perspective they are, they may be quite motivated (and thus, in a sense correct) within the learner language (see Section 3).

A second observation which can be derived from Fig. 1 is that the learners tend to use the posture verbs more frequently in postural and locational contexts (respectively 15\% and 17\%) than the L1 speakers (respectively $4.7 \%$ of postural contexts and $10 \%$ of locational). ${ }^{17}$ Narrowing down these results over the three verbs individually (see Table 2), we see that the tendency towards a greater postural use by the learners especially holds for zitten ( $42.7 \%$ of the cases vs. $13.6 \%$ in the control corpus) and to a lesser extent for staan ( $7.2 \%$ of the cases vs. $4.1 \%$ in the control corpus). ${ }^{18}$ These cases refer to sentences where the sitting or standing position is prominent. As far as the locational contexts in the learner productions are concerned, they appear to be the most frequent for liggen $(38.6 \%$ of the cases vs. 7.3 in the L1 corpus), and zitten (23.6\% of the cases vs. $9.1 \%$ in the control corpus). The latter observation does not apply to staan, however, which is more frequently used in locational contexts by the native speakers (13.7\% of the cases vs. $6.2 \%$ in the learner corpus). Considering the 34 locational uses encoded by liggen in the learner productions, one observes that in a huge majority of the cases $(73.5 \%)$, they refer to sentences expressing a geotopographical location. Other examples of this locational use of liggen concern papers (14.7\% of the cases) or books ( $8.8 \%$ of the cases) lying on a desk. Locational zitten in the L2 data almost exclusively concerns sentences clearly expressing the notion of containment, as in example (8), or to borderline cases taking an intermediate position between posture and location, as in (9).

(8) Aan het begin, zit [...] de hoofdfiguur alleen thuis als de telefoon rinkelt. (DL2-Z-0017)

17. One may wonder (as did one of the reviewers) whether the differences in frequency may not be due to the different topics of argumentative essays in the two corpora. As will be recalled, the learner corpus does indeed contain a larger variety of topics and text types (argumentative essays, summaries, emails and business letters), but none of the topics in either corpus are such that they are biased towards postural or locational uses. The variety in topics does not, in other words, invalidate the major claims made in this paper, such as the overall underuse of the posture verbs by L2-speakers as well as their overusing these verbs in some contexts. Furthermore, the different text types do not affect the qualitative analysis presented in Section 3.

18. The percentages in Table 2 represent the uses per verb; for example, of the 55 attestations for liggen in the control corpus (see Table 1), only 1 is postural $(1.8 \%)$. 
Table 2. Distribution of staan, liggen and zitten across the L1 and L2 corpora

\begin{tabular}{lccccc}
\hline & \multicolumn{2}{c}{ Control } & & \multicolumn{2}{c}{ Learners } \\
\cline { 2 - 5 } & Occ. & $\%$ & & Occ. & $\%$ \\
\hline Postural & $\mathbf{7}$ & $\mathbf{4 . 7}$ & $\mathbf{6 3}$ & $\mathbf{1 5 . 5}$ \\
\hline liggen & 1 & 1.8 & 1 & 1.1 \\
staan & 3 & 4.1 & 15 & 7.2 \\
zitten & 3 & 13.6 & 47 & 42.7 \\
\hline Locational & $\mathbf{1 6}$ & $\mathbf{1 0 . 7}$ & $\mathbf{7 3}$ & $\mathbf{1 7 . 9}$ \\
\hline liggen & 4 & 7.3 & 34 & 38.6 \\
staan & 10 & 13.7 & 13 & 6.2 \\
zitten & 2 & 9.1 & 26 & 23.6 \\
\hline Metaphorical & $\mathbf{6 9}$ & $\mathbf{4 6}$ & $\mathbf{1 2 3}$ & $\mathbf{3 0}$ \\
\hline liggen & 30 & 54.5 & 24 & 27.3 \\
staan & 26 & 35.6 & 75 & 35.9 \\
zitten & 13 & 59.1 & 24 & 21.8 \\
\hline
\end{tabular}

at the beginning, $[\ldots]$ the main character is sitting home alone as the phone rings

(9) Maar roken is niet alleen slecht de mens die rookt, maar ook voor de mensen die erbij zitten. (DL2-Z-0082)

but smoking is not only bad for the smoker, but also for the people 'sitting' with him

In sum, the learners tend to use posture verbs, especially liggen and zitten, to a greater extent than the native speakers in more prototypical contexts denoting posture or location. Conversely, the native speakers use the posture verbs more frequently in metaphorical contexts than the learners ( $46 \%$ of the cases vs. $30 \%$ in the learner productions). This, again, is more striking with liggen and zitten, showing a far greater proportion of metaphorical uses in the productions of the native speakers than in the learners' essays ( $54.5 \%$ vs. $27.3 \%$ for liggen; $59.1 \%$ vs. $21.8 \%$ for zitten). This tendency does not hold for staan, whose metaphorical usage is comparable in both corpora (35.9\% of the cases in the learner corpus vs. $35.6 \%$ in the control corpus). When liggen is used metaphorically by the native speakers, it almost exclusively appears in contexts where it co-occurs with an abstract entity, such as problems, solutions, causes, etc. $(93.3 \%$ of the cases). The remaining metaphorical uses of liggen include contexts where it refers to a conceptualized scalar entity ( $6.7 \%$ of the cases). Al- 
though metaphorical liggen is less frequent in the L2 data, its use by the learners seems to be similar to the native usage, appearing in the first place in combination with abstract entities ( $75 \%$ of the cases), and in the second place in contexts where it refers to a scale ( $25 \%$ of the cases).

Of the 13 occurrences of metaphorical zitten in the productions of the L1-speakers, 12 refer to some abstract notion of containment $(92.3 \%)$, whereas in the remaining example zitten is used as part of a progressive construction. Quite surprisingly, despite its lower frequency in the L2 productions, metaphorical zitten is used in a greater variety of ways by the learners. In addition to a majority of containment uses $(66.6 \%$ of the cases) and two progressive uses ( $8.3 \%$ of the cases), zitten also appears in contexts where it encodes the notion of possession $(8.3 \%$ of the cases, see (10)) and in contexts where it refers to the idea of being stuck $(12.5 \%$ of the cases, see (11)). While this discrepancy between the learner and native usage of metaphorical zitten could probably be explained in terms of the relative size and scope of the control corpus, the observed variety of uses of metaphorical zitten among the learners tend to suggest that some learners correctly manage such very specific metaphorical uses of zitten.

[...] ik zit met een klein probleempje (DL2-Z-0043)

[...] I sit with (= have) a small problem.

De kans bestaat dat de ambitie van de werknemer te hoog of te laag zit. (DL2-Z-0030)

the chance exists that the ambition of the employee sits (= is) too high or too low.

Finally, even though metaphorical staan is as frequent in L2 as in L1, the native speakers and the learners use it in quite different ways. First of all, the native speakers use it more frequently in canonical position contexts, i.e., where the metaphorical use of staan can easily be linked up with its postural or locational meaning. This use of metaphorical staan accounts for $53.8 \%$ of the cases in the L1 corpus. A second context in which metaphorical staan is commonly used in the L1 corpus (34.6\%), is related to the notion of written text as standing entity. Third, $11.5 \%$ of the cases in the control corpus concern metaphorical extensions without a clear link to postural or locational uses. The distribution of metaphorical uses of staan in the L2-corpus is slightly different: the notion of written text as standing entity accounts for $73 \%$ of the cases, followed by the uses referring to canonical position $(21.3 \%)$ and other metaphorical ones $(4 \%)$. The differences internal to the group of metaphorical extensions suggest that L2 speakers do have control of the 'standing text' pattern (a point to which we shall return in 3.2), but their overall semantic map of 
the metaphorical extensions clearly differs from that of the L1 speakers, as could be expected. The L2 speakers probably have not yet mastered the semantic motivations linking up the different uses, as shown by the low frequency of canonical and other metaphorical uses (i.e., other than the 'standing text' pattern).

To conclude the discussion of the overall distributional tendencies, some observations can be made concerning the use of the posture verbs as part of a particle verb and as part of an idiomatic expression. While the former cases are rather limited (4.7\% in L1 and 3.4\% in L2) - all but one example being constructed with staan (vaststaan 'it is clear that', openstaan 'be open to', toestaan 'allow to', etc. but klaarliggen 'be ready'), the group of idiomatic expressions deserves a short discussion.

The occurrence of posture verbs as part of an idiomatic expression occurs more frequently in the $\mathrm{L} 1$ than in the $\mathrm{L} 2$ productions $(33.3 \%$ of the cases vs. $21.6 \%)$. This holds for staan (37\% vs. $29.7 \%)$, liggen $(34.5 \%$ vs. $22.7 \%)$ and zitten $(18.2 \%$ vs. $5.5 \%)$, even though in both corpora such uses appear more regularly with staan and liggen. Frequent expressions with liggen in the L1 data are voor de hand liggen 'lie near the hand (= be evident)' (31.6\%), aan de basis liggen 'lie at the basis of' $(21 \%)$ and in iemands handen liggen 'lie in s.o.'s hands' $(10.5 \%)$. In the learner data, the most frequent examples are voor de hand liggen, ( $40 \%$ of the cases), ergens aan ten grondslag liggen 'lie at the basis of' $(25 \%)$ and iemand na aan het hart liggen 'lie near to s.o.'s heart (= be very dear to someone)' $(15 \%)$. As far as zitten is concerned, its idiomatic uses are quite limited. Both the native speakers and the learners use it in hoe zit het met...? 'how sits it with' (= what about...?) $(50 \%$ of the cases in both $\mathrm{L} 1$ and L2 ) and iets zien zitten 'regard s.th. feasible' (50\% in the L1 corpus vs. $16.6 \%$ in the L2 corpus). In addition, the learners also use zitten in iemand in het haar zitten 'annoy someone' (lit. 'sit s.o. in their hair') (33.3\% of the cases). Finally, idiomatic uses of staan, in opposition to zitten and liggen, show a great diversity of examples among the native speakers (27 occurrences distributed across 17 different expressions; 0.63 Type/Token ratio), as well as among the learners' productions (62 occurrences distributed across 24 different expressions; 0.39 Type/Token ratio). The occurrences of these expressions seem to be quite equally distributed in the L1 corpus; more frequent examples including aan het hoofd staan van 'stand at the head of (= be in charge of)' (11\%), centraal staan 'stand $(=$ be) central' $(11 \%)$ and op eigen benen staan 'stand on your own legs (= be independent)' (11\%). On the other hand, in the L2 data, staan is extensively used as part of the expression centraal staan (29\%), followed by ter beschikking staan 'stand (= be) at one's disposal' $(9.7 \%)$ and in contact staan 'stand $(=$ be) in contact with' $(8 \%)$. 
In sum, even though these expressions are somewhat less frequent in the L2 productions, overall these uses are correct, supporting the idea that these are learnt as fixed units.

\subsection{Quantitative error analysis}

The second step in the quantitative analysis focuses on the different types of errors made by the French-speaking learners when they use staan, liggen and zitten; in Section 3 we will then consider some of these errors from a more qualitative perspective.

As shown in Fig. 1 above, the learners use the posture verbs incorrectly in approximately $11 \%$ of the cases (46 sentences in total). All in all, this is a relatively good result, but this may be attributed to the fact that the corpus consists of written data only, where learners have more time for reflection. It is expected that the error rate in spontaneous speech will be much higher. The highest proportion of errors occurs with staan $(65.2 \%)$, followed by liggen (19.6\%) and zitten (15.2\%).

The different types of errors which have been identified are summarized in Table 6. Recall that these errors all concern cases where a posture verb has been used incorrectly, either (i) because the wrong posture verb was chosen ("posture verb confusion") or (ii) because a posture verb was not possible in the given context ("posture verb panic"). These are the two main categories in Table 6; they will be discussed in more detail below. The third group concerns a collection of miscellaneous cases (i) where it was not at all clear what the speaker was trying to say, (ii) where a posture verb was used instead of a phrasal verb (e.g., toestaan 'allow') ${ }^{19}$, or (iii) where a given construction has not been reproduced correctly (hence, "constructional contamination").

The neat subdivisions in Table 3 concern in reality a much more complicated interplay of factors, especially for the miscellaneous group. At the same time, the division allows us to identify the two main error patterns discussed below, i.e., "posture verb confusion" and "posture verb panic". The subdivisions within these two groups represent an onomasiological perspective, as they identify the context to be encoded, and they do so via the verb that would have been used had the situation been coded correctly. For example, an error labelled "staan:metaphor:text" refers to a sentence expressing the idea of texts located on paper for which

19. These complex verbs probably contribute to the overall posture verb problem, but in line with the decision taken to treat these as a separate category for the correct sentences (see section 1.4 above) we have put these in a separate group here as well. 
Table 3. Types of errors in the learner corpus

\begin{tabular}{lcc}
\hline Context of error & Occurrences & $\%$ \\
\hline 1. POSTURE VERB CONFUSION & $\mathbf{2 0}$ & $\mathbf{4 3 . 5} \%$ \\
\hline liggen-context & $\mathbf{9}$ & $\mathbf{1 9 . 6} \%$ \\
\hline - liggen:metaphor:abstract entity & 1 & $2.2 \%$ \\
- liggen:locational:paper & 3 & $6.5 \%$ \\
- liggen:locational:geotopographical & 5 & $10.9 \%$ \\
\hline staan-context & $\mathbf{6}$ & $\mathbf{1 3 . 1} \%$ \\
\hline - staan:metaphor:text & 5 & $10.9 \%$ \\
- staan:locational:canonical & 1 & $2.2 \%$ \\
\hline zitten-context & $\mathbf{5}$ & $\mathbf{1 0 . 8} \%$ \\
\hline - zitten:metaphor:containment & 2 & $4.3 \%$ \\
- zitten:locational:containment & 2 & $4.3 \%$ \\
- zitten:progressive & 1 & $2.2 \%$ \\
\hline 2. POSTURE vERB PANIC & $\mathbf{1 6}$ & $\mathbf{3 4 . 8} \%$ \\
\hline - existential verb & 10 & $21.7 \%$ \\
- neutral location & 5 & $10.9 \%$ \\
- copula & 1 & $2.2 \%$ \\
\hline
\end{tabular}

\section{MISCELLANEOUS}

\begin{tabular}{lcc}
\hline constructional contamination & 3 & $6.5 \%$ \\
\hline posture verb instead of particle verb & 4 & $8.7 \%$ \\
\hline unclear & 3 & $6.5 \%$ \\
\hline Total & $\mathbf{4 6}$ & $\mathbf{1 0 0} \%$ \\
\hline
\end{tabular}

staan should have been used but for which the learner chose another posture verb.

The following section provides a more detailed analysis of the most common patterns in these two error groups.

\section{Qualitative analysis}

The quantitative analysis above has revealed a number of tendencies that could be summarized as follows:

i. the posture verbs are largely underused in L2 productions;

ii. the different posture verbs are often confused; 
iii. staan is the most frequent verb in the incorrect sentences (30 / 46 or $65.2 \%)$

iv. L2 speakers sometimes use posture verbs where a neutral verb is to be used.

Given the typological differences between Dutch and French, observations (i) and (ii) do not really come as a surprise. The other two observations may not have been intuitively obvious, even if in retrospect they, too, are perhaps not so surprising after all.

The high frequency of staan in the set of errors (regardless of the subdivision drawn up above) lies in line with the verb expressing the canonical position of humans (and entities on their base or in their optimal or functional position). Looking at this from the learner's perspective then, this can be phrased as follows: when learners have identified a context as a "posture verb context", they will most likely choose staan as the "default" posture verb (especially when they have no idea which posture verb to use). Notice that this corresponds nicely with frequency of exposure: the fact that staan refers to canonical posture also makes it the most frequent posture verb in Dutch (cf. Table 1 and the results in Lemmens 2002, 2005b). While it is often said in L2-pedagogy that "what you put in, is not what you get out", the preference for staan as the default verb seems to indicate that L2 speakers do pick up dominant patterns in the target language without being explicitly told. (As a rule, pedagogical grammars do not mention frequency and/or prototypicality.)

Finally, there is the somewhat surprising observation that L2 speakers use posture verbs where Dutch does not allow them. This can certainly in part be attributed to what we conveniently call a general "posture verb panic", that incites L2 speakers to simply replace any form of locational or existential zijn 'be' with a posture verb (a form of hypercorrection); nevertheless, there is still some semantic logic in their behaviour, not unlike that exploited by native speakers, as will be detailed in section 3.1 below. Sections 3.2 and 3.3 will look at the cases where the wrong posture verb is chosen (group 1 in Table 3 above). A number of these errors actually centre around certain well-entrenched substructures ("local prototypes"); in these cases, the link with the postural prototype may no longer be transparent, but this well-entrenched usage motivates new extensions. There are two such structures that we consider here, viz. TEXT AS A STANDING ENTITY (section 3.2) and GEOTOPOGRAPHICAL LOCATION (section 3.3).

\subsection{Overuse of posture verbs}

Given the strong obligation for using a posture verb in Dutch when one wants to express the location of an entity, L2 learners will most likely 
realise the importance of using these verbs at a relatively early stage in their learning process. The high number of metaphorical extensions of these verbs (in the L1-control corpus, about $46 \%$ of the cases) will undoubtedly add to the initial confusion and may lead to some kind of "posture verb panic", inciting learners to use a posture verb in contexts (often metaphorical ones) where no such verb is allowed. Consider the following cases:

(12) a. De vrouw *staat een beetje wanhopig omdat ze wilde dat haar man de tuintrap verft. (DL2-S-0205) ${ }^{20}$

the woman stands a bit desperate because she wanted her husband to paint the gardensteps

b. Geachte Vrouw, Hier *zit de resultaten van mijn verslag. (DL2Z-0059) dear woman (sic), here sits the result of my report

In both cases, the use of a posture verb is inappropriate; the verb zijn 'be' has to be used. The grammaticalisation of posture verbs has not gone that far (yet) that a pure copular use (X BE ADJ) as in (12a) is generally possible, even if there are cases that come quite close (e.g., het huis staat leeg 'the house stands empty'). Yet even for the latter, a certain locative colour remains, whereas in the example here this is not the case. If a locative complement had been added or even a $t e+V$ complement (expressing a progressive), staan would actually have been quite possible: zij staat er wanhopig bij 'she stands there desperately PREP' or zij staat wanhopig tegen haar man te roepen 'she stands desperately to her husband to yell' (= is yelling at). For example (12b) on the other hand, the locative hier 'here' (expressing something like 'enclosed with this letter, herewith') is not locative enough to sanction a posture verb. The use of zitten may have been triggered by the idea of the report being 'attached' to the letter; French joindre 'join' (expressing ATTACHMENT) often takes zitten as the Dutch equivalent.

In some cases, the error may be attributed to a confusion of different idiomatic constructions:

b. In de eerste tekst zoekt men als er een verband *staat tussen de witte massa (DL2-S-0094)

in the first text they (try to) find whether there stands a connection between the white matter

20. For ease of identification, the verb errors in the cited learner examples have been marked with a *; as said before, other mistakes that may occur in the sentences have not been corrected nor have they been marked. 
The two correct expressions, quite similar to each other, are either $X$ staat in verband met $Y$ (' $\mathrm{X}$ stands in connection with $\mathrm{Y}$ ') or $E r$ is een verband tussen $X$ en $Y$ ('there is a connection between $\mathrm{X}$ and $\mathrm{Y}$ '); this seems to be a clear case of "constructional cross-contamination". However, the latter example (as a handful of others) may also be due to a (phonological) confusion of staan and bestaan ('exist'). While bestaan is etymologically related to staan, this is no longer obvious (even native speakers are probably not aware of this) and the verb is often interchangeable with existential zijn. However, one of the L2-errors in our data illustrates that the interchangeability does not always hold:

(14) De kranten zijn meestal goed maar ik vind dat er ook een nadeel *staat... Er zijn bladen die de waarheid niet precies vertellen (DL2S-0130)

the newspapers are usually good but I think that there stands also a disadvantage... There are papers that do not tell the exact truth

Supposing that the L2-speaker confused staan with bestaan, then this would still yield a coding that at best is highly marked, since the verb zijn is the most appropriate alternative. This intuition is confirmed by a Google search on er zijn /bestaan nadelen 'there are/exist disadvantages', yielding 17,500 vs. 3 hits respectively. The reason why bestaan is disfavoured is that it too strongly focuses on the idea of existence, whereas this seems uncalled for in the present context. While the differences between bestaan and zijn appear motivated, a full explanation of these goes beyond the scope of the present paper. ${ }^{21}$

Let us now look at two important subcases where the wrong posture verb is used, triggered by two well-entrenched uses, staan as used to refer to written text (3.2) and liggen as used to refer to geotopographical location (3.3).

\subsection{Text as a standing entity}

The L2 speakers seem to be sufficiently familiar with the Dutch convention of using staan to refer to written text, as it is used correctly in 55 occurrences, which amounts to $30.7 \%$ of their correct uses of staan. At the

21. It is to be expected that this difference will be at least partially similar to that in English between be and exist. Notice that the latter, too, is derived from a Latin verb that referred to standing (ex- 'out, forth' + sistere 'cause to stand'). Similarly, Spanish has estar 'be', which evolved from Latin stare 'stand', whose uses differ from those of the copula ser 'be'. The evolution of estar actually lines in line with the claim that standing is the canonical position for humans. 
same time, there are a number of cases where this context leads to mistakes, either because staan is not being used or because staan is used incorrectly (overextension). Let us begin with the first case; here's one of the L2-examples:

"Zotte mensen" *zit ook tussen aanhalingstekens omdat het een uitdrukking van het meisje is. (DL2-Z-0016)

"crazy people" sits also between quotation marks because it is the expression of (= used by) the girl

The student's choice for zitten is not without motivation, the word being 'closely contained' by the quotation marks; however, talking about the graphemic representation of language renders a coding with staan absolutely compulsory. At the same time, the strong obligation can lead to (subtle) errors as well, as is the case for the following student, inappropriately overextending that use of staan:

(16) Er?*staat een bijbedoeling in de zin die op een verschillende manier geïnterpreteerd zal worden (DL2-S-0160)

there stands a hidden intention in the sentence that will be interpreted in a different way

At first glance, nothing seems wrong with this example, since the student is talking about the text that will be interpreted differently. However, upon second thought, the formulation just does not seem fully idiomatic, since a hidden intention is not really orthographically expressed, unlike is the case with straightforward meanings, where this metonymy does apply, e.g., Hun ideeën staan in het werkboek 'their ideas stand in the workbook' (Google example). ${ }^{22}$ A coding with zitten (expressing containment) would thus have been more idiomatic.

Despite the fact that basically any text can be said to have a meaning 'sitting' in it, there are certain conventionalised collocations, as becomes apparent from the following L2-error, where the learner is talking about the information in newspapers:

(17) Maar als je [die kranten] eens koopt, ontdekt je dat daar niets in *zit (DL2-Z-0055)

but when you buy [these newspapers], you discover that there sits nothing in them

Apparently, this learner has mastered the usage of zitten to refer to the meaning 'inside' texts, yet a native speaker of Dutch would immediately

22. http://www.zinweb.nl/content/leeszin/boek.asp?oId=359, last accessed Jan. 12, 2009. 
replace the verb with staan to render the sentence more idiomatic. ${ }^{23}$ The reason for this is that in newspaper articles, and generally all other types of non-fictional prose, meanings should be directly derivable from the very words themselves since these texts are not supposed to have hidden meanings. In Dutch postural logic, their meaning thus 'stands' on the paper, black on white. It is obviously not impossible for these texts to have a 'deeper layer of meaning' (implications, humour, sensitivity, etc.), yet such is typically not associated with them. ${ }^{24}$ Rather, these are the things one finds in fictional prose, poems or song lyrics. Notice, however, that if the meaning is sufficiently evident from the words/text itself, staan remains a preferred coding even in these types of texts.

In sum, what the above L2-examples reveal is that the learners are aware of certain common extensions of staan (printed text) and zitten ((close) containment), as further illustrated by the higher frequency of theses uses (see in section 2.1) that are generally also quite frequent in the L1 data. At the same time, the learners may not have fully mastered some of the collocational subtleties of the target language, which themselves are semantically well-motivated (which, unfortunately, we cannot afford to elaborate on here).

\subsection{Geotopographical location}

One of the extensions that is common for liggen is to express "geotopographical location", which concerns the location of entities that are typically conceived of as locations themselves, such as buildings, cities, villages, etc. This usage is quite frequent in the learner data: there are 29 occurrences in the L2-corpus, which amounts to $33 \%$ of the total attestations for liggen (88); only 2 of these are incorrect (cf. below). Conversely, there are 5 contexts of geotopographical location where the L2-learner uses staan instead of liggen, of which 4 are given in example (18) below ( 2 were by the same speaker, so only one of those is given).

23. Notice that this sentence would be appropriate if the speaker were referring to extra things that one may find in a newspaper, such as loose advertisement brochures, a concert calendar or other loose sections/quires you can take out, free stickers of CDs enclosed with it, etc. Such physical containment is, however, not referred to in this particular context.

24. A simple Google search on "in de krant zit" yielded only 2 examples (as opposed to 8,160 for "in de krant staat") referring to this context (and not to the one mentioned in the previous footnote) where the located entities were niet genoeg diepgang 'not enough depth' and zoveel emotie 'so much emotion'; they essentially confirm the tendencies described here. 
a. de landen die vlak bij de zee *staan... (DL2-S-0012) the countries that stand close to the sea

b. terwijl Gosselies... verder van Charleroi *staat (DL2-S-0114) while Gosselies stands further away from Charleroi ${ }^{25}$

c. Daar *staat een beautycenter met sauna, bubbelbad en massages. (DL2-S-0158)

there stands a beauty centre with sauna, jacuzzi and massages

d. De universiteit *staat in Luik en ik houd veel van deze stad (DL2-S-0200)

the university stands in Liège and I love this city very much

For (18a) and (18b) there is absolutely no discussion: the location of land areas and cities must be coded with liggen. For (18c) and (18d), the situation is more complex, since the two buildings could be conceived of as 'standing' (a vertical entity resting on its base). However, in the context at hand, such a focus on the building is rather infelicitous. Interestingly, one erroneous use of liggen in this context misses precisely on this point:

(19) Bauval [beweert] dat de piramiden van Gizeh op een bepaalde wijze ?*liggen in overeenstemming met het midden van het sterrenbeeld Orion. (DL2-L-0026)

Bauval claims that the Gizeh pyramids lie in a certain way in accordance with the middle of the Orion constellation

Overall, this is a context of geotopographical location, and liggen is possibly acceptable; the reason why it has been marked as an error, is that the sentence talks about the pyramids being deliberately positioned in a certain way, which renders their canonical position (resting/put on their base) again salient, and the use of staan would have been more idiomatic.

There is one particular case where a learner seems to overextend the geotopographical context to one that is not really one:

(20) Voor een steeds betere dienstverlening zal de geldverdeler buiten het kantoor *liggen (DL2-L-0030)

to provide an increasingly better service the cash dispenser will lie outside the bank office

Usually, cash dispensers are built into the wall and do not occupy a land surface of their own, which makes the use of liggen very marked; rather a coding with a more general location verb such as zich bevinden 'be lo-

25. Gosselies and Charleroi are two cities in the French-speaking part of Belgium. 
cated' is preferred. One could say that the use of liggen here creates a "Google Maps"-effect which is inappropriate for entities not usually conceived of as locations having $(\mathrm{x}, \mathrm{y})$ coordinates.

We can say that, at least judging on the data used for this study, that L2-learners have mastered this use of liggen fairly well, interferences probably being most common in the context of buildings and the like for which a coding variation liggen/staan is mostly possible, even if the context usually guides the language user to a clear preference.

\section{Conclusions and prospects}

Our pilot study of the use of the Dutch posture verbs staan, liggen and zitten by French-speaking learners has unravelled some interesting tendencies. In our quantitative analysis of the data, we firstly observed that the learners underuse these verbs in their productions as could be expected given the typological differences between French and Dutch regarding the expression of posture and location. Considering the specific contexts in which the posture verbs have been used correctly by the learners, we have further shown that they use them far more frequently in postural and locational contexts, whereas the native speakers tend to use them more frequently in metaphorical contexts. This observation suggests that the learners are more inclined to use the posture verbs in their basic contexts, being less at ease with their metaphorical extensions. These distributions lend support to the idea that the coding flexibility is a major difficulty for the learners when faced with the wide range of extensions staan, liggen and zitten.

Refining our analysis revealed, however, that the learners appear to master some specific patterns of the metaphorical uses of the posture verbs, such as zitten expressing containment or possession, staan referring to text as standing entity or liggen expressing the location of abstract entities. Our qualitative analysis even pointed out that the learners tend to overextend certain of these metaphorical patterns. Similarly, the qualitative analysis has revealed some other cases of overgeneralisation whereby the learners resorted to a posture verb in contexts in which a more general verb would have been more natural ("posture verb panic").

This overuse of certain patterns not only shows that the L2 user has probably mastered the logic of certain specific uses, but also that they are exploiting these insights to encode similar situations. In doing so, they will inevitably overgeneralise or ignore collocational patterns of the target language that L1 speakers have acquired through massive and repeated exposure to linguistic input. The absence of a L1 acquisition 
control corpus motions to extreme caution, yet on the basis of the L2 patterns discussed above (and ignoring issues of cognitive development and maturity), we are inclined to conclude that, in general terms, L2 acquisition strategies may exploit the same principles as what one observes for L1. Clearly, given the high frequency of posture verbs in Dutch and the problems these entail, the language learner may sometimes decide to play "safe" and blindly apply a posture verb in contexts where their native language might have guided them to using a location verb such as zijn ('be') or zich bevinden ('be found'). However, looking at the errors in question reveals that L2 speakers do follow general overextension strategies that characterise L1 acquisition as well (cf. Brown 1958; Clark 2003: 211-212; Tomasello 2003: 127-8). ${ }^{26}$ In other words, these errors are not "blind" but reveal at least a partial insight into the linguistic system. While some hypercorrection cannot be excluded, their insight is clearly in line with the input data, as shown, for example, by the high frequency of staan in the errors or by the recurrent use of some expressions such as centraal staan ('stand central').

Considering the (recurrent) use of certain specific metaphorical patterns of the posture verbs has allowed us to evaluate to what extent the learners master the semantic network of the verb in question. In line with a usagebased approach, our claim, partly supported by the observation that the learners seem to have a good control of expressions with posture verbs, is that the learners, when assimilating a new pattern of use of a posture verb, might rather learn it as an separate unit and miss insights as to how the different nuances of a given posture verb relate to each other, preventing them to integrate the new pattern into the verb's semantic network. To put it another way, having mastered some specific metaphorical uses of a given posture verb does not mean that the learners master the whole semantic structure of the category. Some of the patterns that the L2-learner has to uncover may be relatively straightforward, such as "use staan when coding the location of an entity on its base", or "use liggen for a symmetrical object located in space", or "use zitten when an entity is closely contained by another". Other cases, some of which were discussed here (but there are many others), remain problematic, as it may not always be clear from an (encoding) point of view whether a neutral verb is to be used or rather a posture verb and if so, which one. This is

26. As we have not yet looked at L1 acquisition of posture verbs, we are not claiming that the actual patterns of extension are necessarily the same; the suggestion is that the general extension mechanisms, as revealed through overextension, are exploited by both. 
particularly true for certain collocational patterns for which the internal motivation may not be so easy to discover. In line with a usage-based view on language acquisition, it is expected that the L2 language learner may eventually unravel these via the same interplay of factors that the L1 language learner operates with, i.e., frequency of input, implicit and explicit negative input and statistical pre-emption (cf. Tomasello 2003; Goldberg 2006).

Summing up then, our analysis appears to support two important interrelated claims. The first one is that it is incorrect to consider the learner system as simply an imperfect version of the target language; rather, it is a linguistic system in its own right that follows a mixed logic: some of the "errors" are due to interferences from their native language (in our case, the underuse of posture verbs) yet others are due to overextensions of patterns they observe in the target language, as illustrated above. The second observation, which follows logically from the first and which, moreover, has important pedagogical consequences, is that input plainly matters, also for L2 acquisition: L2 speakers do pick up dominant patterns in the target language without being explicitly told (cf. also Rast 2008) and they apply these creatively.

The corpus-study reported on here is obviously but a first (yet necessary) step to unravel the processes at work in L2 acquisition of Dutch posture verbs. Despite its limitations, mainly related to corpus size and the type of texts, our study has allowed us to discover some general patterns in the errors produced by the learners, which might have been more difficult to observe in a controlled experimental setting. This particularly concerns the metaphorical uses of the posture verbs.

Further research is obviously warranted and will be pursued along two paths. Firstly, extending the existing contrastive research for L1 as described in Lemmens (2005a), we will carry out elicitation experiments where francophone L2 speakers describe the location of entities as given by a controlled set of illustrations and compare these (semi-spontaneous) narrations to those produced by native speakers. Secondly, we will do follow-up experiments probing into intuitions of L1 and L2 speakers concerning some of the onomasiological variations described above. It is to be expected that this research will confirm the tendencies outlined here and provide further insight into the L2 language system. Finally, in order to fully evaluate the suggestion that the L1 and L2 acquisition strategies for posture verbs are comparable, a more systematic analysis of the acquisition of these verbs in $\mathrm{L} 1$ is warranted. 


\section{References}

Ameka, Felix K. and Stephen. C. Levinson. 2007. The typology and semantics of locative predicates: posturals, positionals, and other beasts. Linguistics 45. 847-871.

Brown, Roger. 1958. How shall a thing be called? Psychological Review 65. 14-21.

Clark, Eve V. 2003. First language acquisition. Cambridge: Cambridge University Press.

Fagan, Sarah. 1991. The Semantics of the positional predicates liegen/legen, sitzen/setzen, and stehen/stellen. Die Unterrichtpraxis 24.136-145.

Goldberg, Adèle E. 2006. Constructions at work: The nature of generalization in language. Oxford: Oxford University Press.

Guirardello-Damian, Raquel. 2002. The syntax and semantics of posture forms in Trumai. In Newman, John (ed.), The linguistics of sitting, standing and lying (Typological Studies in Language 51), 141-177. Amsterdam and Philadelphia: John Benjamins.

Gullberg, Marianne. To appear. Language-specific encoding of placement events in gestures. In Eric Pederson and Jürgen Bohnemeyer (eds.), Event representations in language and cognition. Cambridge: Cambridge University Press.

Gullberg, Marianne and Bhuvana Narashimhan. This volume. Gestures and the development of semantic distinctions in Dutch.

Hiligsmann, Philippe. 1997. Linguïstische aspecten en pedagogische implicaties van de tussentaal van Franstalige M.O.-leerders van het Nederlands [Linguistic aspects and pedagogical implications of the interlanguage of French M.O. learners of Dutch]. Genève and Liège: Droz, Bibliothèque de la Faculté de Philosophie et Lettres de l'Université de Liège.

Klein. Wolfgang. 2008. From the learner's point of view. Paper presented at the International Conference on Language acquisition: Comparative perspectives. Paris, 5-6 December.

Klein, Wolfgang and Clive Perdue (eds.). 1993. Adult language acquisition: Cross-Linguistic perspectives. Cambridge: Cambridge University Press.

Kutscher, Silvia and Eva Schultze-Berndt. 2007. Why a folder lies in the basket although it is not lying: the semantics and use of German positional verbs with inanimate Figures. Linguistics 45. 983-1028.

Lemmens, Maarten. 2001. LOCATION versus POSITION: Coding strategies for referent location Paper presented at the ICLC7, University of California, Santa Barbara, California, 22-27 July.

Lemmens, Maarten. 2002. The semantic network of Dutch posture verbs. In John Newman (ed.), The linguistics of sitting, standing and lying. (Typological Studies in Language 51), 103-139. Amsterdam and Philadelphia: John Benjamins.

Lemmens, Maarten. 2005a. Motion and location: toward a cognitive typology. In Geneviève Girard (ed.), Parcours linguistiques. Domaine anglais. (CIEREC Travaux 122), 223-244. St. Etienne: Publications de l'Université St Etienne.

Lemens, Maarten. 2005b. Aspectual posture verb constructions in Dutch. Journal of Germanic Linguistics 17. 183-217.

Lemmens, Maarten. 2006. Caused posture: experiential patterns emerging from corpus research. In Anatol Stefanowitsch and Stephan Gries (eds), Corpora in cognitive linguistics: Corpus-based approaches to syntax and lexis. Berlin: Mouton de Gruyter, 261-296.

Lemmens, Maarten and Dan I. Slobin. 2008. Positie- en bewegingswerkwoorden in het Nederlands, het Engels en het Frans. In Philippe Hiligsmann, Mélanie Baelen, Anne-Lore Leloup and Laurent Rasier (eds), Verslagen en mededelingen van de Koninklijke Academie voor Nederlandse Taal- en Letterkunde 118, 17-32.

Newman, John. 2002. A cross-linguistic overview of the posture verbs 'sit', 'stand', and 'lie'. In John Newman (ed.), The linguistics of sitting, standing and lying. (Typological Studies in Language 51), 1-24. Amsterdam and Philadelphia: John Benjamins. 
Newman, John and Sally Rice. 2004. Patterns of usage for English SIT, STAND, and LIE: A cognitively inspired exploration in corpus linguistics. Cognitive Linguistics 15. 351-396. Perrez, Julien and Liesbeth Degand. In preparation. Het Leerdercorpus Nederlands (Cahiers du Cental X). Presses universitaires de Louvain.

Rast, Rebekah. 2008. Foreign language input: Initial processing. Clevedon: Multilingual Matters.

Serra Borneto, Carlo. 1996. Liegen and stehen in German: A study in horizontality and verticality. In Eugene Casad (ed.), Cognitive linguistics in the Redwoods, 458-505. Berlin: Mouton de Gruyter.

Talmy, Leonard. 2000. Towards a Cognitive Semantics (Vol. 1 and 2). Cambridge, MA: MIT-press.

Tomasello, Michael. 2003. Constructing a language. A usage-based theory of language acquisition. Cambridge, MA.: Harvard University Press.

Van Oosten, Jeanne. 1984. Sitting, Standing and Lying in Dutch: A Cognitive Approach to the Distribution of the Verbs Zitten, Staan, and Liggen. In Jeanne van Oosten \& Johan Snapper (eds.), Dutch linguistics at Berkeley, UCB. 137-160.

Vuillermet, Marine. 2008. Ese Ejja posture verbs do not just sit there: An inquiry into other ways they stand out. Paper presented at the Workshop for American Indigenous Languages, University of California, Santa Barbara, 23-24 May. 